\title{
SUDAH SAMPAI MANAKAH RISET KEUANGAN MIKRO SYARIAH KITA?
}

\author{
Aam S. Rusydiana ${ }^{1}$
}

${ }^{1}$ Afiliasi: SMART Indonesia. Email: aamsmart@gmail.com

\begin{abstract}
ABSTRAK. Penelitian ini mencoba review penelitian seputar lembaga keuangan mikro syariah. Penelitian ini menggunakan analisis statistik deskriptif berdasarkan 100 publikasi jurnal terpilih yang berhubungan dengan LKMS, baik jurnal nasional maupun internasional. Sampel publikasi jurnal tersebut dipublikasikan selama 10 tahun terakhir dari 2007 hingga 2016. Hasil menunjukkan bahwa penelitian LKMS masih didominasi oleh tema pembahasan (isu) tentang LKMS (54\%), diikuti oleh isu mengentaskan kemiskinan (25\%), kemudian isu pembiayaan LKMS terhadap masyarakat miskin atau kurang mampu (11\%), dan terakhir tentang manajemen LKMS (10\%). Indonesia, Malaysia, dan Pakistan menjadi area studi LKMS terbanyak, sementara area publikasi terbanyak yaitu dari Indonesia, United States dan United Kingdom. Selain itu, perbandingan penelitian kuantitatif dan metode campuran (mixed method) masih lebih sedikit dibandingkan dengan pendekatan penelitian kualitatif.
\end{abstract}

Kata Kunci: Literatur LKMS, Isu LKMS, dan Penelitian LKMS

\begin{abstract}
This study tries to review the research around Islamic microfinance institution. It uses descriptive statistical analysis based on selected 100 journal publications or paper related to Islamic microfinance institution, both national and international journal. The entire sample journal publications have published for ten years from 2007 to 2016. The Results show that Islamic microfinance institute research is still dominated by the discussion about Islamic microfinance institution (54\%), followed by eradication of poverty (25\%), then financing the poor societies (11\%) and the last is about management of Islamic microfinance institution (10\%). In addition, Indonesia, Malaysia and Pakistan are being the highest of Islamic microfinance study area, while the majority of publications area are from Indonesia, United States and United Kingdom. Furthermore, the comparison of quantitative research and mixed methods are still less than the qualitative approach.
\end{abstract}

Keywords: Islamic microfinance institution Literatures, Islamic microfinance issues, and Research on Islamic microfinance institution

\section{PENDAHULUAN}

Substansi kemiskinan adalah kondisi deprevasi terhadap sumbersumber pemenuhan kebutuhan dasar yang berupa sandang, pangan, papan, dan pendidikan dasar (Sudibyo, 1995). Kemiskinan adalah salah satu problematika utama yang dihadapi oleh berbagai negara termasuk Negara Indonesia. Selama ini, pengentasan kemiskian yang dilakukan oleh pemerintah cukup signifikan yang mengalami penurunan dari tahun ke tahun, di mana menurut data Badan 
Pusat Statistik, tingkat kemiskinan relatif Indonesia pada tahun 2006 sebesar 17,8\% dan pada tahun 2014 sebesar $11 \%$.

Di samping itu, tingkat disparitas pendapatan antar masyarakat Indonesia cenderung tergolong tinggi. Hal ini dapat dibuktikan dengan angka indeks gini Indonesia sebesar 0.40 pada akhir tahun 2015 (BPS dan Bank Dunia). Secara umum, pola pengentasan kemiskinan Indonesia cenderung bersifat kedermawanan. Pola ini akan berdampak langsung dalam memperburuk moral dan perilaku masyarakat.

Dalam rangka mewujudkan masyarakat Indonesia yang sejahtera, maka dapat dilakukan upaya pengentasan kemiskinan dengan langkah yang lebih konkret yaitu dengan memberdayakan masyarakat miskin itu sendiri. Sehingga langkah tersebut tidak hanya dapat mengentaskan kemiskinan melainkan juga dapat memperbaharui disparitas pendapatan antar masyarakat Indonesia. Salah satu bentuk pemberdayaan masyarakat kurang mampu (unit defisit) yaitu berupa suntikan modal untuk melakukan usaha melalui Lembaga Keuangan Mikro.

Menurut Mu'alim dan Abidin (2005), lembaga keuangan mikro syariah Baitul Mal wat Tamwil (BMT) adalah kelompok swadaya masyarakat sebagai lembaga ekonomi rakyat yang berupaya mengembangkan usaha-usaha produktif dan investasi dengan konsep utamanya adalah sistem bagi hasil untuk meningkatkan kualitas ekonomi pengusaha kecil dalam upaya pengentasan kemiskinan.

Lembaga Keuangan Mikro memiliki pengaruh yang signifikan dalam memberdayakan masyarakat kurang mampu untuk hidup lebih sejahtera. Begitu pun Indonesia, LKM maupun LKMS berkontribusi signifikan terhadap perekonomian nasional. Hal ini didukung dengan berkembangnya jumlah institusi keuangan mikro yang didorong oleh kebutuhan masyarakat Indonesia terhadap kehadiran LKM, terlebih khusus bagi masyarakat yang kesulitan dalam mengakses pembiayaan dari bank. Selain faktor kebutuhan atau permintaan masyarakat, adanya pertumbuhan Usaha Mikro, Kecil dan Menengah (UMKM) juga menjadi faktor pendorong berkembangnya LKM di Indonesia. UMKM mampu berkontribusi sebesar 57,48 persen terhadap Produk Domestik Bruto (PDB). Dengan demikian, UMKM memiliki peran dalam menopang perekonomian Indonesia (Ascarya dan Yumanita, 2007).

Bank Indonesia meluncurkan program akses keuangan untuk semua (financial inclusion) pada tahun 2010 sebagai program untuk mengentaskan kemiskinan dan mendorong pertumbuhan ekonomi. Lembaga Keuangan Mikro memiliki keselarasan dengan program tersebut yang dapat mengatasi permasalahan rendahnya akses modal keuangan (Hadinoto dan Retnadi, 2012).

Perekonomian Indonesia dapat dikatakan memiliki fundamental yang kuat, jika ekonomi rakyat telah menjadi pelaku utama yang produktif dan berdaya saing dalam perekonomian nasional. Maka dari itu, pembangunan ekonomi rakyat melalui pemberdayaan Usaha Mikro menjadi prioritas utama pembangunan ekonomi nasional dalam jangka panjang (Deperindag, 2002). Selain Indonesia, negara- negara berkembang dan negara Muslim lainnya memberikan pandangan bahwa Lembaga keuangan mikro memiliki peran 
Jurnal Ekonomi dan Perbankan Syariah

Vol. 6. No.1, April 2018: 0-26, ISSN (cet): 2355-1755 | ISSN (online): 2579-

6437

17

penting dalam meningkatkan kualitas hidup masyarakatnya. Hal ini ditunjukkan dengan adanya perkembangan penelitian Lembaga Keuangan Mikro dari tahun ke tahun.

Dari latar belakang tersebut, penulis tertarik untuk membahas mengenai perkembangan riset terkait keuangan mikro (microfinance) syariah selama 10 tahun terakhir (2007-2016). Beberapa manfaat yang bisa didapat dari penelitian ini yaitu mengetahui sudah sejauh mana potret perkembangan keuangan mikro syariah di Indonesia dan negara lainnya. Serta bagaimana perhatian keuangan mikro syariah terhadap masalah kesulitan akses pembiayaan dan masalah pengentasan kemiskinan di antara masyarakat yang kurang mampu.

\section{LANDASAN TEORI}

\subsection{Lembaga Keuangan Mikro Syariah}

Lembaga Keuangan Mikro merupakan lembaga intermediasi keuangan pada level mikro baik formal maupun non formal yang didirikan dan dimiliki bersama oleh warga masyarakat untuk memecahkan masalah permodalan dan kebutuhan dana yang dihadapi para anggotanya, dalam rangka mengembangkan usaha produktif, meningkatkan pendapatan dan kesejahteraan keluarga.

Menurut definisi yang dikeluarkan Micro Credit Summit (1997), Keuangan Mikro adalah "Program pinjaman uang terhadap keluarga miskin untuk digunakan sebagai usaha yang memberikan hasil dan income dalam memenuhi kebutuhan pribadi dan keluarganya" (Ascarya dan Sanrego: 2007). Definisi tersebut menjelaskan bahwa lembaga keuangan mikro baik itu syariah ataupun tidak, diperuntukkan untuk keluarga miskin. Dan dana tersebut digunakan untuk memulai atau menambah modal sebuah usaha sehingga dengan usaha tersebut keluarga miskin memiliki income tambahan yang digunakan untuk keperluan dan kebutuhannya sehari-hari.

Berdasarkan Bank Indonesia, LKM di Indonesia dibagi menjadi dua bagian yaitu LKM yang berwujud bank dan non-bank. LKM yang berwujud bank adalah BRI Unit Desa, Danamon Simpan Pinjam (DSP), Bank Perkreditan Rakyat (BPR) dan Badan Kredit Desa (BKD). Sedangkan yang bersifat non- bank yaitu Koperasi Simpan Pinjam (KSP), Unit Simpan Pinjam (USP), Lembaga Dana Kredit Pedesaan (LDKP), Baitul Mal wat Tamwil (BMT), Lembaga Swadaya Masyarakat (LSM), dan lainnya.

Menurut Arifin (2001), setelah diundangkannya UU No. 7/1992 tentang perbankan bagi hasil mulai diakomodasikan, berdirilah Bank Mu'amalat Indonesia (BMI) yang merupakan Bank Umum Syariah (BUS) pertama yang beroperasi di Indonesia. Kemudian diikuti oleh pendirian bank-bank perkreditan rakyat Syari'ah (BPRS). Namun karena dirasakan kurang mencukupi dan belum sanggup menjangkau masyarakat Islam lapisan bawah, maka dibangunlah lembaga- lembaga simpan pinjam yang disebut Baitul Maal wat Tamwil (BMT) (Astuti: 2007). 
Baitul Maal wat Tamwil (BMT) merupakan pengembangan dari konsep ekonomi dalam Islam terutama dalam keuangan. Istilah BMT adalah penggabungan dari Baitul Maal dan Baitul Tamwil. Baitul Maal adalah lembaga keuangan yang kegiatannya mengelola dana yang bersifat nirlaba (sosial). Sumber dana Baitul Maal diperoleh dari zakat, infak, dan sodaqoh atau sumber-sumber lain yang sifatnya halal. Kemudian dana tersebut disalurkan kepada mustahik dan digunakan untuk hal-hal yang sifatnya untuk kebaikan. Sedangkan Baitul Tamwil adalah lembaga keuangan yang kegiatannya menghimpun dan menyalurkan dana masyarakat yang sifatnya profit oriented. Penghimpunan dana diperoleh melalui simpanan para anggota, simpanan pihak ketiga dan penyalurannya dilakukan dalam bentuk pembiayaan atau investasi yang dijalankan berdasarkan prinsip syari'ah (Widodo, 1999).

Senada dengan Rasidi (2007), ada dua bagian dari BMT yang masingmasing istilah memiliki fungsi dan pengertian yang berbeda. Pertama, Baitul Maal merupakan lembaga penerima zakat, infak, sadaqoh (ZIS) dan sekaligus menjalankannya sesuai dengan peraturan dan amanahnya. Sedangkan Baitul Tamwil adalah lembaga keuangan yang berorientasi bisnis dengan mengembangkan usaha-usaha produktif dan investasi dalam meningkatkan kualitas kehidupan ekonomi masyarakat terutama masyarakat dengan usaha skala kecil.

Lembaga Keuangan Mikro Syariah (LKMS) di Indonesia disebut juga dengan istilah Baitul Maal wat Tamwil (BMT) atau secara hukum disebut Koperasi Jasa Keuangan Syariah (KJKS). Payung hukum dari pendirian BMT di Indonesia adalah Keputusan Menteri Koperasi dan UKM No 91/Kep/MKUKM/IX/2004 tentang petunjuk pelaksanaan kegiatan usaha Koperasi Jasa Keuangan Syariah. BMT dirancang sebagai lembaga ekonomi rakyat, yang secara konsepsi dan secara nyata lebih fokus kepada masyarakat bawah, yang miskin dan nyaris miskin. Agenda kegiatannya yang utama adalah pengembangan usaha mikro dan usaha kecil, terutama melalui bantuan permodalan (Buchori: 2012).

\subsection{Prinsip Lembaga Keuangan Mikro Syariah (LKMS)}

Pelaksanaan usaha LKMS berdasarkan pada prinsip utama sebagai berikut (Rusydiana dan Devi, 2013):

1. Keimanan dan ketaqwaan kepada Allah SWT dengan mengimplementasikan pada prinsip- prinsip syari'ah dan muamalah islam ke dalam kehidupan nyata.

2. Keterpaduan, yakni nilai-nilai spritual dan moral menggerakkan etika bisnis yang dinamis, proaktif, progresif, adil dan berakhlaq mulia.

3. Kekeluargaan, yakni mengutamakan kepentingan bersama di atas kepentingan pribadi. Semua pengelolah pada setiap tingkatan, pengurus dengan semua lininya serta anggota, dibangun rasa kekeluargaan, sehingga akan tumbuh rasa saling melindungi dan menanggung.

4. Kebersamaan, yakni kesatuan pola pikir, sikap dan cita-cita antar semua elemen LKMS. Antara pengelola dan pengurus harus memiliki satu visi 
dan bersama-sama anggota untuk memperbaiki kondisi ekonomi dan sosial.

5. Kemandirian, yakni mandiri di atas semua golongan politik. Mandiri juga berarti tidak tergantung dengan dana-dana pinjaman dan"bantuan" tetapi senantiasa proaktif menggalang dana masyarakat sebanyak-banyaknya.

6. Profesionalisme, yakni semangat kerja yang tinggi, yakni dilandasi dengan dasar keimanan. Kerja yang tidak hanya berorientasi pada kehidupan dunia saja, tetapi juga kenikmatan dan kepuasan ruhani dan akhirat. Kerja keras dan cerdas yang dilandasi dengan bekal pengetahuan yang cukup, keterampilan yang terus ditingkatkan serta niat dan ghirah yang kuat. Semua itu dikenal dengan kecerdasan emosional, spritual dan intelektual. Sikap profesionalisme dibangun dengan semangat untuk terus belajar demi mencapai tingkat standar kerja yang tertinggi.

7. Istiqomah, konsisten, konsekuen, kontinuitas/berkelanjutan tanpa henti dan tanpa pernah putus asa. Setelah mencapai suatu tahap, maka maju lagi ke tahap berikutnya dan hanya kepada Allah SWT kita berharap.

\subsection{Pembiayaan}

Pembiayaan merupakan penyediaan uang atau tagihan yang dapat dipersamakan dengan itu, berdasarkan persetujuan atau kesepakatan antara bank dengan pihak lain yang mewajibkan pihak yang dibiayai untuk mengembalikan uang atau tagihan tersebut setelah jangka waktu tertentu dengan imbalan atau bagi hasil (Undang-Undang Perbankan Nomor 10 tahun 1998).

Antonio (2001) disebutkan bahwa pembiayaan adalah pemberian fasilitas penyediaan dana untuk memenuhi kebutuhan pihak-pihak yang merupakan unit defisit.

Pembiayaan mikro (Microfinance) merupakan suatu usaha meningkatkan akses pinjaman dan untuk menyelamatkan masyarakat yang memiliki pendapatan dan kesejahteraan rendah serta merupakan cara terbaik untuk mengurangi kemiskinan (Schreiner, 1999). Menurut Bank Indonesia kredit mikro adalah kredit yang diberikan kepada para pelaku usaha produktif baik perorangan maupun kelompok yang mempunyai hasil penjualan paling banyak Rp. 100 juta per tahun. Perbedaan dasar antara Lembaga Keuangan Mikro dan Lembaga Keuangan Mikro Syariah terletak pada sistem bagi hasil.

\subsection{Efektifitas Pembiayaan BMT}

Saefuddin (1980) dinyatakan bahwa efektifitas penyaluran kredit (pembiayaan) pedesaan ditentukan oleh kemampuannya menjangkau sebanyak mungkin masyarakat pedesaan yang benar- benar membutuhkan modal bagi usahanya. Jangkauan pelayanan tersebut dipengaruhi oleh kemudahan pengambilan kredit, yang dilihat dari persyaratan yang harus dipenuhi nasabah, prosedur pengambilan kredit, jangka waktu pencairan dan pelunasan kredit serta kecepatan pelayanan. 


\subsection{Fokus Kajian}

Kajian dalam penelitian ini memfokuskan pada eksplorasi terhadap 100 penelitian up to date terkait lembaga keuangan mikro syariah (microfinance) yang telah terpublikasi pada jurnal ilmiah. Ada beberapa isu yang hendak diketahui jawabannya. Umpamanya, berapa persentase riset terkait Islamic microfinance selama 10 tahun terakhir. Bagaimana jenis/tipe penelitian Islamic microfinance dan komposisinya. Bagaimana pendekatan penelitian tentang Islamic microfinance dikaitkan dengan penggunaan metode penelitian baik kuantitatif, kualitatif maupun metodologi campuran (mixed method).

Selain yang tersebut di atas, fokus kajian juga mencoba menelaah lebih dalam terkait apa saja metode penelitian kuantitatif yang dipakai dan apa yang dominan dipakai. Apa saja yang menjadi subjek pembahasan terkait Islamic microfinance dan komposisinya.

Penelitian ini menggunakan analisis statistika deskriptif berdasarkan 100 publikasi jurnal terkait Islamic microfinance, baik nasional maupun internasional. Seluruh sampel publikasi jurnal telah terpublikasi selama 10 tahun terakhir mulai tahun 2007 hingga 2016. Studi hanya memfokuskan secara spesifik terhadap tulisan jurnal bertema Islamic microfinance.

Selanjutnya, setelah dilakukan review dan analisis, penelitian terkait Islamic microfinance ini dibagi ke dalam empat kategori utama yaitu: 1). Manajemen Keuangan Mikro, 2). Keuangan Mikro dan Pengentasan Kemiskinan, 3). Institusional Keuangan Mikro, dan 4). Akses pembiayaan. Termasuk ke dalam term institusional adalah kelembagaan, payung hukum dan regulasi tentang keuangan mikro. Pengklasifikasian ini dibuat berdasarkan penelaahan isi, abstraksi dan keseluruhan penelitian secara umum. Meskipun tidak menutup kemungkinan terjadinya irisan-irisan kategori dan klasifikasi.

\section{METODOLOGI PENELITIAN}

\subsection{Jenis dan Sumber Data}

Penelitian ini menggunakan data sekunder selama periode 2007- 2016 yang sudah dipublikasikan sebagai jurnal ilmiah baik nasional maupun internasional terkait Lembaga Keuangan Mikro syariah (Islamic microfinance). Jurnal- jurnal tersebut dapat diperoleh atau diakses secara online dari jurnal yang telah dipublikasikan.

Metodologi yang digunakan dalam penelitian ini adalah, 1) pendekatan metode kualitatif dengan statistik deskriptif studi literatur terhadap 100 jurnal dan riset tentang Islamic microfinance. Metode penelitian kualitatif adalah metode penelitian yang berlandaskan pada filsafat postpositivisme digunakan untuk meneliti pada kondisi objek yang alamiah, (sebagai lawannya adalah eksperimen) dimana peneliti adalah sebagai instrument kunci, teknik pengumpulan data dilakukan secara triangulasi (gabungan), analisis data bersifat induktif/kualitatif, dan hasil penelitian kualitatif lebih menekankan makna dari pada generalisasi (Sugiyono: 2008).

Penelitian kualitatif bersifat deskriptif. Data yang dianalisis tidak untuk menerima atau menolak hipotesis (jika ada). Hasil analisis tersebut berupa deskripsi atas gejala-gejala yang diamati dan tidak harus berbentuk angka- 
Jurnal Ekonomi dan Perbankan Syariah

Vol. 6. No.1, April 2018: ○-26, ISSN (cet): 2355-1755 | ISSN (online): 2579-

6437

11

angka atau koefisien antar variabel (Subana dan Sudrajat: 2005). Penelitian ini diolah dengan menggunakan Ms. Excel.

\subsection{Statistika Deskriptif}

Statistik deskriptif merupakan bidang ilmu statistik yang mempelajari cara- cara pengumpulan, penyusunan dan penyajian ringkasan data penelitian. Data- data tersebut harus diringkas dengan baik dan teratur, baik dalam bentuk tabel atau presentasi grafik, sebagai dasar untuk berbagai pengambilan keputusan (Wijaya: 2013).

\subsection{Metode Sampling}

Penelitian ini menggunakan metode sampling non probabilitas purposive. Sampel bertujuan (purposive) adalah sampel yang memiliki tujuan untuk memahami informasi tertentu. Sampel ini dapat dikelompokkan menjadi sampel keputusan (judgment) yang memilih anggota- anggota sampel yang sesuai dengan beberapa kriteria tertentu atas dasar catatan yang lalu atau tujuan penelitian yang ingin dicapai, dan sampel kuota yaitu sampel dipilih berdasarkan kuota atau kategori tertentunya, memilih responden atas karakteristik relevan tertentu yang menggambarkan dimensi- dimensi (proporsi) populasi (Wijaya: 2013). Kriteria yang dimaksud dalam penelitian ini yaitu publikasi jurnal terkait keuangan mikro dari tahun 2007-2016.

\section{ANALISIS DAN PEMBAHASAN}

\subsection{Jumlah Publikasi per Tahun}

Pada bagian ini menjelaskan jumlah publikasi jurnal dari tahun 2007 hingga 2016. Terdapat 100 jurnal yang terpublikasi baik jurnal nasional maupun internasional yang berhubungan dengan Islamic microfinance dari observasi 10 tahun terakhir. Gambar 1 menjelaskan distribusi jurnal per tahun yang menunjukkan jumlah jurnal terpublikasi bervariasi dari tahun 2007 hingga 2016 dengan range 3 hingga 24 jurnal. Adapun publikasi jurnal terkait Islamic microfinance terbanyak yaitu pada tahun 2013 (24\%). Sedangkan publikasi jurnal yang lebih sedikit dibandingkan tahun lainnya yaitu pada tahun $2008(3 \%)$. 


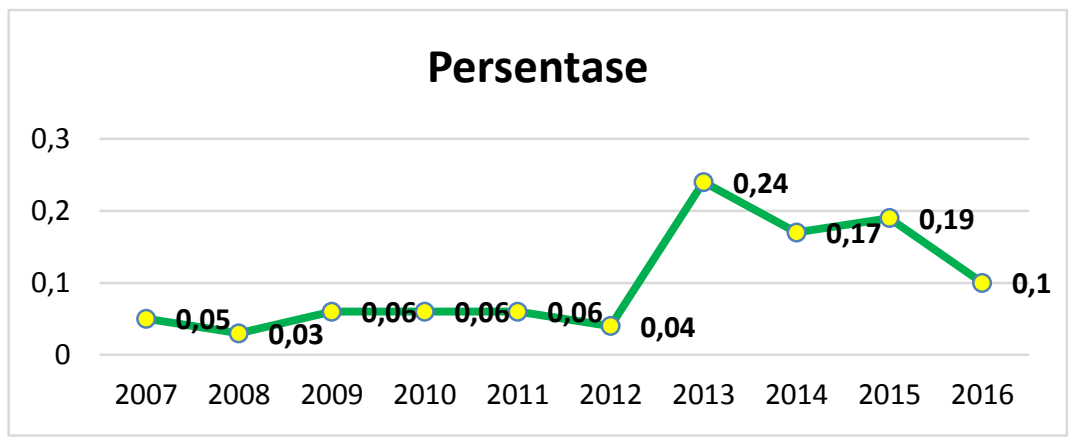

Grafik 1. Jumlah Publikasi per Tahun

\subsection{Jenis Penelitian dari Masing- Masing Publikasi}

Tabel 1 menunjukkan jenis (tipe) penelitian yang digunakan untuk setiap publikasi jurnal yang diamati. Menurut Sekaran (2013), secara umum terdapat empat tipe penelitian yaitu analisis, deskriptif, empiris, dan penelitian eksploratori. Dalam observasi ini, hanya menggunakan tiga jenis tipe penelitian yaitu analisis, deskriptif dan empiris.

Pertama, penelitian analisis digunakan untuk mencoba menjawab persoalan mengapa hal tertentu atau bagaimana hal tersebut dapat terjadi. Jenis penelitian ini biasanya berhubungan dengan sebab akibat. Kedua, penelitian deskriptif mencoba untuk menentukan, menggambarkan, atau mengidentifikasi hal tertentu. Penelitian deskriptif menggunakan deskripsi, klasifikasi, pengukuran, dan perbandingan untuk menggambarkan suatu fenomena. Dan ketiga, metode penelitian empiris yaitu metode penelitian yang menggunakan observasi studi lapangan (empiris) atau data yang terkumpul dari tanya jawab seperti dalam bentuk kuisioner.

Dari tabel 1 dapat diketahui bahwa jenis metodologi penelitian yang terbanyak digunakan dari jurnal terpublikasi baik jurnal nasional dan internasional terkait Islamic microfinance selama tahun 2007 hingga 2016 yaitu jenis penelitian deskriptif sejumlah 55 jurnal (55\%), kemudian diikuti oleh jenis penelitian analisis sejumlah 27 jurnal (27\%) dan terakhir yaitu jurnal yang menggunakan penelitian empiris sebanyak 18 jurnal (18\%).

Tabel 1. Jenis Penelitian dari Masing- Masing Publikasi

\begin{tabular}{|r|c|c|c|c|}
\hline \multirow{2}{*}{ Year of Publication } & \multicolumn{3}{|c|}{ Research Types } & \multirow{2}{*}{ Total } \\
\cline { 2 - 4 } & Analytical & Descriptive & Empirical & \\
\hline $\mathbf{2 0 0 7}$ & 0 & 4 & 1 & $\mathbf{5}$ \\
\hline $\mathbf{2 0 0 8}$ & 0 & 3 & 0 & $\mathbf{3}$ \\
\hline $\mathbf{2 0 0 9}$ & 0 & 6 & 0 & $\mathbf{6}$ \\
\hline $\mathbf{2 0 1 0}$ & 3 & 3 & 0 & $\mathbf{6}$ \\
\hline $\mathbf{2 0 1 1}$ & 0 & 6 & 0 & $\mathbf{6}$ \\
\hline $\mathbf{2 0 1 2}$ & 2 & 1 & 1 & 4 \\
\hline $\mathbf{2 0 1 3}$ & 10 & 9 & 5 & $\mathbf{2 4}$ \\
\hline $\mathbf{2 0 1 4}$ & 5 & 7 & 5 & $\mathbf{1 7}$ \\
\hline $\mathbf{2 0 1 5}$ & 4 & 11 & 4 & $\mathbf{1 9}$ \\
\hline $\mathbf{2 0 1 6}$ & 3 & 5 & 2 & $\mathbf{1 0}$ \\
\hline & $\mathbf{2 7}$ & $\mathbf{5 5}$ & $\mathbf{1 8}$ & $\mathbf{1 0 0}$ \\
\hline
\end{tabular}


Jurnal Ekonomi dan Perbankan Syariah

Vol. 6. No.1, April 2018: 0-26, ISSN (cet): 2355-1755 | ISSN (online): 2579-

6437

\section{3}

\subsection{Pendekatan Penelitian Masing- Masing Publikasi}

Berdasarkan Punch (2013), ada 3 jenis pendekatan penelitian yaitu pendekatan kualitatif, pendekatan kuantitatif dan pendekatan metodologi campuran (mixed method). Tabel 2 menunjukkan metodologi penelitian yang digunakan untuk setiap jurnal terpublikasi dalam kurun waktu 10 tahun yaitu 2007 hingga 2016. Dalam observasi ini, pendekatan penelitian yang terbanyak digunakan adalah pendekatan kualitatif sejumlah 70 jurnal $(70 \%)$. Kemudian pendekatan kuantitatif sejumlah 28 jurnal (28\%) dan terakhir yaitu jurnal yang menggunakan pendekatan kombinasi (mixed method) sejumlah 2 jurnal (2\%).

Tabel 2. Pendekatan Penelitian Masing- Masing Publikasi

\begin{tabular}{|r|c|c|c|c|}
\hline \multirow{2}{*}{ Year of Publication } & \multicolumn{3}{|c|}{ Research Types } & \multirow{2}{*}{ Total } \\
\cline { 2 - 5 } & Qualitative & Quantitative & Mixed & \\
\hline $\mathbf{2 0 0 7}$ & 5 & 0 & 0 & 5 \\
\hline $\mathbf{2 0 0 8}$ & 3 & 0 & 0 & $\mathbf{3}$ \\
\hline $\mathbf{2 0 0 9}$ & 6 & 0 & 0 & $\mathbf{6}$ \\
\hline $\mathbf{2 0 1 0}$ & 3 & 3 & 0 & $\mathbf{6}$ \\
\hline $\mathbf{2 0 1 1}$ & 6 & 0 & 0 & $\mathbf{6}$ \\
\hline $\mathbf{2 0 1 2}$ & 2 & 2 & 0 & $\mathbf{4}$ \\
\hline $\mathbf{2 0 1 3}$ & 13 & 10 & 1 & $\mathbf{2 4}$ \\
\hline $\mathbf{2 0 1 4}$ & 11 & 6 & 0 & $\mathbf{1 7}$ \\
\hline $\mathbf{2 0 1 5}$ & 14 & 4 & 1 & $\mathbf{1 9}$ \\
\hline $\mathbf{2 0 1 6}$ & 7 & 3 & 0 & $\mathbf{1 0}$ \\
\hline Total & $\mathbf{7 0}$ & $\mathbf{2 8}$ & $\mathbf{2}$ & $\mathbf{1 0 0}$ \\
\hline
\end{tabular}

Terkait jenis metodologi penelitian kuantitatif yang digunakan dalam jurnal publikasi yang diobservasi, metode yang paling banyak digunakan adalah sebagai berikut: metode Deskriptif Statistik - Kuisioner (9 jurnal), Single-Multiple Regression Analysis/ OLS (7 jurnal), Logit Model (5 jurnal), Analytic Network Process/ ANP (4 jurnal), Data Envelopment Analysis/ DEA (3 jurnal), dan metodologi lainnya seperti Principal Component Analysis, Two Stage DEA, Structural Equation Modelling/SEM, ANOVA, PLS, SWOT Analysis, Probit, Business Modelling yang masing-masing satu jurnal.

\subsection{Subjek Jurnal Islamic Microfinance}

Tabel 3 menunjukkan subjek pembahasan masing-masing jurnal terkait Islamic Microfinance berdasarkan publikasi jurnal Islamic Microfinance selama tahun 2007 hingga 2016. Adapun dalam observasi ini berdasarkan empat subjek yaitu terkait manajemen LKMS, akses pembiayaan, pengentasan kemiskinan, dan Institusional LKMS. Dari publikasi jurnal 2007- 2016 terpilih dalam pengamatan, subjek pembahasan terkait jurnal Islamic Microfinance terbanyak yaitu mengenai institusi LKMS sejumlah 54 jurnal (54\%) dari 100 sampel jurnal, kemudian diikuti oleh subjek pembahasan mengenai pengentasan kemiskinan sejumlah 25 jurnal (25\%), kemudian akses 
pembiayaan sejumlah 11 jurnal (11\%), dan manajemen LKMS sejumlah 10 jurnal (10\%).

Tabel 3. Subjek Pembahasan Jurnal Islamic Microfinance

\begin{tabular}{|l|r|r|r|r|r|r|r|r|r|r|r|}
\hline \multirow{2}{*}{ Subject of Article } & \multicolumn{7}{|c|}{ Year of Publication } & \multirow{2}{*}{ Total } \\
\cline { 2 - 13 } & $\mathbf{2 0 0 7}$ & $\mathbf{2 0 0 8}$ & $\mathbf{2 0 0 9}$ & $\mathbf{2 0 1 0}$ & $\mathbf{2 0 1 1}$ & $\mathbf{2 0 1 2}$ & $\mathbf{2 0 1 3}$ & $\mathbf{2 0 1 4}$ & $\mathbf{2 0 1 5}$ & $\mathbf{2 0 1 6}$ & \\
\hline Management & 0 & 0 & 1 & 1 & 1 & 0 & 3 & 3 & 1 & 0 & $\mathbf{1 0}$ \\
\hline Financing & 0 & 0 & 1 & 1 & 1 & 0 & 1 & 1 & 4 & 2 & 11 \\
\hline Poverty & 2 & 0 & 2 & 2 & 1 & 2 & 5 & 3 & 7 & 1 & $\mathbf{2 5}$ \\
\hline Institution & 3 & 3 & 2 & 2 & 3 & 2 & 15 & 10 & 7 & 7 & $\mathbf{5 4}$ \\
\hline Total & $\mathbf{5}$ & $\mathbf{3}$ & $\mathbf{6}$ & $\mathbf{6}$ & $\mathbf{6}$ & $\mathbf{4}$ & $\mathbf{2 4}$ & $\mathbf{1 7}$ & $\mathbf{1 9}$ & $\mathbf{1 0}$ & $\mathbf{1 0 0}$ \\
\hline
\end{tabular}

\subsection{Area Studi dan Publikasi Berdasarkan Negara}

Tabel 4 menunjukkan daftar terbanyak publikasi berdasarkan letak geografis (negara). Tabel ini dibagi menjadi 2 bagian yaitu lokasi studi 100 jurnal publikasi terpilih dan area publikasi jurnal tersebut. Pada bagian pertama, mengenai lokasi atau area studi jurnal. Dari tabel 4 dapat diketahui bahwa Indonesia, Malaysia dan Pakistan menjadi area studi terbanyak terkait penelitian Islamic Microfinance yaitu sejumlah 35 jurnal (Indonesia) 11 jurnal (Malaysia) dan 9 jurnal (Pakistan). Kemudian diikuti oleh Bangladesh, India, Nigeria dan Yaman (masing- masing 3 jurnal), Australia dan Iran (masingmasing 2 jurnal), dan Thailand (1 jurnal) dan negara lainnya.

Senada dengan area studi, dari segi area publikasi jurnal, Indonesia menjadi negara yang terbanyak publikasi terkait penelitian Islamic Microfinance sejumlah (22 jurnal), United State (11 jurnal), United Kingdom (9 jurnal), Malaysia (8 jurnal), Pakistan (6 jurnal), Bangladesh, India dan Kanada (masing- masing 3 jurnal), Australia, Belanda, Iran, Italia, Spanyol, Turkey, dan UAE (masing- masing 2 jurnal, Sisanya adalah negara-negara lain.

Adapun area publikasi dari 100 jurnal Islamic microfinance terpilih bervariasi yaitu terdapat 70 lebih jenis jurnal. Dalam penelitian Islamic microfinance ini, Humanomics menjadi jurnal terbanyak dalam mempublikasikan jurnal terkait Islamic microfinance yaitu sejumlah 5 jurnal, kemudian diikuti oleh Tazkia Islamic Finance and Business Review (4 jurnal), Asian Social Sciences dan Al-Iqtishad (masing- masing 3 jurnal), Middle East Journal of Scientific Research, Journal of Islamic Finance, Journal of Islamic Economics, Banking and Finance, Australian Journal of Basic and Applied Sciences (masing- masing 2 jurnal), dan jurnal lainnya 1 jurnal. 
Jurnal Ekonomi dan Perbankan Syariah

Vol. 6. No.1, April 2018: ○-26, ISSN (cet): 2355-1755 | ISSN (online): 2579-

6437

15

Tabel 4. Area Studi dan Publikasi Berdasarkan Negara

\begin{tabular}{|l|c|l|c|}
\hline \multicolumn{1}{|c|}{ Country } & Studied Area & \multicolumn{1}{c|}{ Country } & Publication Area \\
\hline Indonesia & 35 & Indonesia & 22 \\
\hline Malaysia & 11 & Amerika - USA & 11 \\
\hline Pakistan & 9 & Inggris - UK & 9 \\
\hline Bangladesh & 3 & Malaysia & 8 \\
\hline India & 3 & Pakistan & 6 \\
\hline Nigeria & 3 & Bangladesh & 3 \\
\hline Yaman & 3 & India & 3 \\
\hline Australia & 2 & Kanada & 3 \\
\hline Iran & 2 & Australia & 2 \\
\hline Thailand & 1 & Belanda & 2 \\
\hline Inggris - UK & 0 & Iran & 2 \\
\hline Kanada & 0 & Italia & 2 \\
\hline Amerika - USA & 0 & Spanyol & 2 \\
\hline Belanda & 0 & Turkey & 2 \\
\hline Italia & 0 & UAE & 2 \\
\hline UAE & 0 & Thailand & 1 \\
\hline Spanyol & 0 & Yaman & 1 \\
\hline Others & 28 & Others & 19 \\
\hline Total & $\mathbf{1 0 0}$ & Total & $\mathbf{1 0 0}$ \\
\hline
\end{tabular}

\subsection{Temuan Penelitian}

Ada beberapa temuan penelitian terkait penelitian ini. Analisis 100 publikasi jurnal terkait studi Islamic microfinance dari tahun 2007 hingga 2016 adalah sebagai berikut:

a. Terdapat keragaman pembahasan jurnal terkait Islamic microfinance yang terpublikasi telah didiskusikan. Jumlah publikasi terbanyak yaitu pada tahun 2013 sebanyak 24 jurnal dari 100 sampel jurnal terpublikasi.

b. Umumnya penggunaan metode penelitian deskriptif untuk menjawab fenomena Islamic microfinance di suatu negara tertentu masih mendominasi metode penelitiannya yaitu sejumlah 55 jurnal $(55 \%)$ dari 100 sampel jurnal. Sedangkan metode penelitian analisis 27 jurnal (27\%) dan metode penelitian empiris sebanyak 18 jurnal (18\%).

c. Secara umum dari 100 publikasi jurnal menggunakan metode pendekatan kualitatif dalam membahas Islamic microfinance sebanyak 70 jurnal (70 $\%)$, pendekatan kuantitatif 28 jurnal (28\%), dan pendekatan mixed method 2 jurnal (2\%) dari $100 \%$.

d. Subjek pembahasan 100 publikasi jurnal Islamic microfinance tersebut lebih banyak terkait institusi $L K M S$, kemudian disusul terkait pengentasan kemiskinan, akses pembiayaan dan terakhir yaitu terkait manajemen LKMS. 
e. Indonesia, Malaysia dan Pakistan menjadi area studi Islamic microfinance terbanyak dari 100 sampel publikasi jurnal terpilih dibandingkan negara lainnya. Di samping itu, jurnal-jurnal Indonesia, United State dan United Kingdom menjadi terbanyak dalam publikasi jurnal tentang Islamic microfinance.

Hasil dari analisis di atas dapat diketahui bahwa isu Islamic microfinance menjadi pembahasan yang intensif oleh pakar- pakar Muslim dari tahun ke tahun. Hal ini persoalan yang dihadapi oleh berbagai negaranegara berkembang dan negara Islam yaitu terkait pengentasan kemiskinan. Dari 100 sampel jurnal, subjek pembahasan institusi LKMS dan pengentasan kemiskinan menjadi subjek prioritas para peneliti selama 10 tahun terakhir untuk dijadikan kebijakan yang berdampak domino dan signifikan dalam peningkatan kualitas hidup manusia. Selain itu, isu- isu tentang Islamic microfinance lebih banyak dikaji atau dibahas dengan menggunakan metode deskriptif dan kualitatif.

\section{KESIMPULAN DAN REKOMENDASI}

Penelitian tentang Islamic microfinance memiliki peran penting untuk umat Islam dalam menyadari pentingnya pemberdayaan manusia untuk mendapatkan kualitas hidup yang lebih baik dengan adanya kemudahan akses pembiayaan. Selain itu, dapat mengentaskan kemiskinan dan menyejahterakan masyarakat. Area Studi penelitian Lembaga Keuangan Mikro maupun Lembaga Keuangan Mikro Syariah masih didominasi oleh negara- negara berkembang. Hal ini menjadi bukti bahwa LKM-LKMS memiliki potensi meningkatkan agregat perekonomian masyarakat negara berkembang melalui pemberdayaan masyarakatnya dengan salah satu cara akses pembiayaan yang mudah. Pembahasan penelitian Islamic microfinance didominasi oleh pembahasan institusi LKMS dan pengentasan kemiskinan dari tahun 2007 hingga 2016. Selain itu, perbandingan metode penelitian kuantitatif masih lebih sedikit dibandingkan dengan pendekatan kualitatif. Hal ini menjadi potensi untuk meningkatkan penelitian selanjutnya tentang Islamic microfinance dengan menggunakan metode kuantitatif.

\section{DAFTAR PUSTAKA}

Antonio, M. S. (2001). Bank Syariah: Dari Teori ke Praktek. Gema Insani Press, Jakarta.

Ascarya dan Sanrego, Y D. (2007). Redefine Micro, Small, and Medium Enterprises Classification and the Potency of Baitul Maal wat Tamwiel as Intermediary Institutions in Indonesia, Jurnal Ekonomi dan Bisnis Islam Edisi 2.

Ascarya dan Yumanita D. (2007). "The Profile of Micro, Small, and Medium Enterprises in Indonesia and the Strategy to Enhance Islamic Financial Services through Baitul Maal wat Tamwiel". Paper the $2^{\text {nd }}$ Islamic Conference (iECONS2007) Kuala Lumpur. 
Jurnal Ekonomi dan Perbankan Syariah

Vol. 6. No.1, April 2018: 0-26, ISSN (cet): 2355-1755 | ISSN (online): 2579 -

6437

17

Astuti, E M B. (2007). Evaluasi Tingkat Pendapatan Usaha Kecil Sebelum dan Sesudah Memperoleh Pembiayaan dari BMT Beringharjo, Kauman, Yogyakarta. [Skripsi].

Buchori N. S. (2012). Koperasi Syariah. Tangerang Selatan: Pustaka Aufa Media.

Deperindag. (2002). Rencana Induk Pengembangan Industri Kecil Menengah

2002-2004. Departemen Perindustrian dan Perdagangan, Jakarta.

Hadinoto, S dan Retnadi, J. (2012). Micro Credit Challenge, Cara Efektif

Mengatasi Kemiskinan dan Pengangguran di Indonesia. Jakarta: Elex

Media Computindo.

Mu'alim, A dan Abidin M Z. (2005). Profesionalisme Praktisi BMT di Kota Yogyakarta dan Kabupaten Sleman, Millah 4(2).

Rasidi, A. (2007). Mengenal Baitul Maal Wat Tamwil.

Rusydiana, A S dan Devi, A. 2013. Mengurai Masalah dan Solusi Pengembangan Lembaga Keuangan Mikro Syariah di Indonesia: Pendekatan Metode BOCR ANP. $2^{\text {nd }}$ Best Paper at National Islamic Economic Call Paper and Seminar (NIECS), Airlangga University: Surabaya.

Saefuddin, A. M. (1980). Perkreditan Petani Kecil. Jurusan Sosial Ekonomi Pertanian. Fakultas Pertanian. IPB. Bogor.

Schreiner, M. (1999). A Cost Effectiveness Analysis of the Grameen Bank of Bangladesh.

Subana dan Sudrajat. (2005). Dasar-dasar Penelitian Ilmiah. Bandung: Pustaka Setia, hlm. 17.

Sudibyo, B. (1995). Substansi Kemiskinan dan Kesenjangan di Indonesia Dalam Kemiskinan dan Kesenjangan di Indonesia. Diedit oleh Dewanda, dkk. Yogyakarta: Aditya Media. Hal 11-14.

Sugiyono. 2008. Metode Penelitian Kuantitatif, Kualitatif, dan R\&D. Bandung: Alfabeta, hlm.9.

Widodo, H. (1999). Panduan Praktis Operasional Baitul Maal wat Tamwil (BMT), Dompet Duafa Republika.

Wijaya, T. (2013). Metodologi Penelitian Ekonomi dan Bisnis Teori dan Praktek. Yogyakarta: Graha ilmu. Hal 28- 37.

\section{Publikasi Jurnal Keuangan Mikro Syariah (Jurnal Nasional \& Internasional)}

\section{Tahun 2016}

Ahamad, S, Bakar R, dan Lubis, Z. (2016). Islamic Microfinance and Its Impacts on Borrowers: A Systematic Review from 1995-2015, Mediterranean Journal of Social Sciences Vol 7(6).

Asmy, M dan Hassanudin. (2016). Adopting Zero Interest Financing Model (ZIFM) in Islamic Microfinance Institutions; the Case of Shariah 
People Credit Bank (BPRS), Indonesia, SHS Web of Conferences 23, 02003.

Effendi, J dan Utami, A. R. (2016). The Effect of Social Capital on Customer's Repayment Rate at Islamic Microfinance Institution, Al- Iqtishad: Jurnal Ilmu Ekonomi Syariah Vol. 8(2), pp 227-242.

Ibrahim, B El Din A. (2016). Microfinance in Sudan and Ethiopia, Journal of Islamic Banking and Finance, Vol. 33(1), pp. 25-38.

Muhtarom, M. (2016). Reformulasi Peraturan Hukum Lembaga Keuangan Mikro Syariah di Indonesia, PROFETIKA, Jurnal Studi Islam, Vol. 17(1), pp. 90-102.

Mursal. (2016). Pengembangan Lembaga Keuangan Mikro Syariah di Sumatera Barat Berbasis Kearifan Lokal “Tungku Tigo Sajarangan”, Analytica Islamica Vol. 5(1), pp. 108-124.

Rahman, R. A dan Dean F. (2016). Challenges and Solutions in Islamic Microfinance, Humanomics Vol. 29(4), pp 293-306.

Riaz, M dan Qasim M. (2016). Islamic Microfinance Institution; the Capital Structure Growth, Performance and Value of the Firm in Pakistan, Journal of ISOSS Vol. 2(1), pp. 97-101.

Usman, A. S dan Tasmin, R. (2016). The Role of Islamic Micro-finance in Enhancing Human Development in Muslim Countries, Journal of Islamic Finance Vol 5(1), pp. 053-062.

Zubair, M. K. (2016). Analisis Faktor-Faktor Sustainabilitas Lembaga Keuangan Mikro Syariah, Iqtishadia Vol. 9(2), pp. 201-226.

\section{Tahun 2015}

Adnan, M A dan Ajija, S. R. (2015). The Effectiveness of Baitul Maal wat Tamwil in Reducing Poverty, The Case of Indonesian Islamic Microfinance Institution, Humanomics, Vol. 31(2), pp. 160-182.

Ali, A R E S. (2015). Islamic Microfinance; Moving Beyond Financial Inclusion, European Scientific Journal Vol. 11(10).

Alshebami, A. S dan Khandare, D. M. (2015). Islamic Microfinance Industry in Yemen Challenges and Opportunities, International Journal of Social Work Vol. 2(2).

Amalia, E dan Atiqah, M. (2015). Evaluating the Models of Sharia Microfinance in Indonesia, An ANP Approach, Al- Iqtishad, Vol. 7(1).

Chakrabarty, A. K. (2015). Islamic Microfinance: an Interest Free Microfinance Model for Poverty Alleviation, Journal of Economics and Business Research, Vol. 21(2), pp. 15-31.

Elwardi, D. (2015). The role of Islamic Microfinance in Poverty Alleviation; Lessons from Bangladesh Experience, MPRA.

Ferawati, R, Juanda, B, Syaukat, Y, Bratakusumah, D. S. (2015). Domination of Murabaha Financing of Islamic Microfinance in Developed and Underdeveloped Areas In Bogor Regency, International Journal of Research in Social Sciences Vol. 5(5). 
Jurnal Ekonomi dan Perbankan Syariah

Vol. 6. No.1, April 2018: 0-26, ISSN (cet): 2355-1755 | ISSN (online): 2579-

6437

19

Hassanain, K. M. (2015). Integrating Zakah, Awqaf and IMF for Poverty Alleviation; Three Models of Islamic Micro Finance, Journal of Economic and Social Thought Vol. 2(3).

Mahmood, H. Z, Fatima, M, Khan, M dan Qamar, M A. (2015). Islamic Microfinance and Poverty Alleviation: An Empirical Ascertainment from Pakistan, Journal of Islamic Economics, Banking and Finance, Vol. 11(2).

Mohamed, I S, Rozzani, N, Rashidah, A R. (2015). Development of Local Exchange Trading System for Islamic Microfinance Institution, Recent Advances on Finance Science and Management.

Mansori, S, Kim, C S dan Safari, M. (2015). A Shariah Perspective Review on Islamic Microfinance, Asian Social Science, Vol. 11(9).

Masood, S, Qamar, M. A. J dan Qamar, A. A. (2015). Microfinance and Disasters; Islamic Microfinance a New Paradigm to Serve the Unserved, J. Appl. Environ. Biol. Sci., Vol. 5(8), pp. 7-16.

Mulyaningsih, Y, Nuryartono, N, Oktaviani, R dan Firdausy, C. M. (2015). The Impact of Access to Islamic microfinance Institutions (Islamic MFI) on poverty alleviation in rural Bogor West Java; A Propensity Score Matching Approach, Global Journal of Commerce and Management Perspective, Vol. 4(5), pp. 9-16.

Phupoxsakul, K dan Lewis, S. L. (2015). Microfinance and Family Ties; Challenge to Reduce the Loan Default in Urban Area in Thailand, Southeast Asian Journal of Economics Vol. 3(2), pp. 61-90.

Rachmawati, D. E. (2015). Market opportunity and regulation microfinance in Indonesia, Journal of East Asian Studies, No. 13, pp. 173-191.

Rahman, R. A, Smady, A, dan Kazemian, S. (2015). Sustainability of Islamic Microfinance Institutions through Community Development, International Business Research, Vol. 8(6).

Rehman, H, Moazzam, A dan Ansari, N. (2015). Role of Microfinance Institutions in Women Empowerment; A Case Study of Akhuwat, Pakistan, Journal of South Asian Studies, Vol. 30(1), pp. 107-125.

Rudrabhatla, R, Roy, S, dan Bose, S. K. (2015). Role of Microfinance and Microfinance Institutions Models in Improving Quality Of Life- A Critical Review, International Journal of Engineering, Business and Enterprise Applications 15-234.

Thambiah, S, Muthaiyah, S dan Jun K J. (2015). Islamic Microfinance Participation among Women Entrepreneurs in Malaysia: A Conceptual Framework, Middle-East Journal of Scientific Research Vol. 23(9).

\section{Tahun 2014}

Abbas, K, Razak, D A, dan Saad, N. (2014). The Perception of Microentrepreneurs and Petty Traders on Conventional and Islamic Microfinance; A Case Study of Pakistan, Journal of Islamic Finance, Vol. 3(1), pp. 038-048. 
Ahmad, M K. (2014). Islamic Microfinance- A Conceptual Framework, Episteme: an Online Interdisciplinary, Multidisciplinary and MultiCultural Journal, Vol. 3(3).

Ahmad, Z, Norhasniza, Nur, L, Ramdhan, N, Hassan, S, Ruziah A L, Suhana, M, Jaffar, H H, Muharratul, S dan Malik S A. (2014). A Review on Microfinancing; Conventional and Islamic Financing, Australian Journal of Basic and Applied Sciences, Vol. 8(20), pp. 27-35.

Amran, A M, Rashidah, A R, Sharifah, N, Mohamed I S. (2014). The current practice of Islamic microfinance institutions Accounting Information System via the Implementation of Mobile Banking, Procedia Social and Behavioral Sciences 145, pp. 81-87.

Aslam, M N. (2014). Role of Islamic Microfinance in Poverty Alleviation in Pakistan; an Empirical Approach, International Journal of Academic Research in Accounting, Finance and Management Sciences, Vol. 4(4), pp. 143-152.

Fararah, F S, Swidi, A K, Sulaiman, W. (2014). Business Development Services Provided by Islamic Microfinance Institutions and Customer Satisfaction the Mediation Role of Perceived Benefits. A Study on SMEs in Yemen, Journal of Entrepreneurship and Business Innovation, Vol. 1(1).

Girona E F, Aghina, G, dan Boundaoui, I. (2014). Islamic Microfinance in Yemen, Egypt and Indonesia.

Isola, L A, Taiwo, O E, Victor, A, dan Leke, B K. (2014). An Enquiry into the Contributions of Microfinance Institutions towards the Development of Small Scale Business in Nigeria, International Journal of Business, Economics and Management, Vol. 1(6), pp. 88-100.

Khurshid, U dan Zaman, K. (2014). Micro Finance to Islamic Micro Finance; Akhuwat Model, Journal of Economic Info, Vol. 1(1), pp. 11-22.

Mahmood, H Z, Khan, R, Mehmood, B dan Khan, M. (2014). Efficiency Analysis of Conventional vs. Islamic Microfinance; an Appraisal for Sustainability in Pakistan, International Journal of Empirical Finance, Vol. 3(4), pp. 192-201.

Mihajat, M I S dan Amalia, E. (2014). Micro Financing Products and Business Model of Islamic Micro Finance Institution (Imfis) In Indonesia Lessons from BMM, EJBM-Special Issue: Islamic Management and Business, Vol. 2(2).

Niazi, K. (2014). Microfinance: Does Religion Explain the Low Take Up Rate? Evidence from India.

Nugroho, L. (2014). Challenges Sharia Microfinance Institutions; Evidence from Indonesia, European Journal of Islamic Finance No. 1.

Rizal. (2014). Peran Perempuan Dalam Pengembangan Lembaga Keuangan Mikro Syariah di Kabupaten Tanah Datar, Human Falah Vol. 1(1).

Sabi, M. (2014). Islamic Microfinance in Kyrgyztan dan Tajikistan.

Sultan, J. (2014). Poverty Alleviation and Islamic Microfinance, Bentley Microfinance Review, Vol. 2(1), pp. 1-13. 
Jurnal Ekonomi dan Perbankan Syariah

Vol. 6. No.1, April 2018: ^-26, ISSN (cet): 2355-1755 | ISSN (online): 2579-

6437

| 21

Widiarto, I dan Emrouznejad, A. (2014). Social and Financial Efficiency of Islamic Microfinance Institutions: A Data Envelopment Analysis Application, Socio- Economic Planning Sciences.

\section{Tahun 2013}

Abdelkader, I B dan Salem, A B. (2013). Islamic vs Conventional Microfinance Institutions; Performance analysis in MENA countries, International Journal of Business and Social Research, Vol. 3(5).

Aisyah, M. (2013). The Network Triangle and Societal Sector Institutions,

Methodological Approach on Islamic Microfinance to Micro Entrepreneurs in Indonesia, Jurnal Etikonomi Vol. 12(2).

Arabi, S H dan Meisami, H. (2013). The Concept and Fundamentals of Islamic Microfinance and prospect for its introduction in Iran, Journal of Islamic Finance and Business Research, Vol. 2(1), pp. 1-12.

Ascarya. (2013). Microfinance Model for Micro Enterprises to Support Sustainable Rural Development, International Conference on Sustainable Rural Development 2013: Sustainable Rural Development.

Fararah, F S dan Swidi A K. (2013). The Role of the Perceived Benefits on the Relationship between Service Quality and Customer Satisfaction, A Study on the Islamic Microfinane and SMEs in Yaman using PLS Approach, Asian Social Science, Vol. 9(10).

Hakimi, M dan Ajeerah, A. (2013). Farmers' Practices in Developing Agricultural Land in Malaysia: Is there an Islamic Micro-finance Solution?, Tazkia Islamic Finance and Business Review Vol. 8(2).

Hasanah, A dan Yusuf A A. (2013). Determinants of the Establishment of Islamic Micro Finance Institutions; the case of BMT in Indonesia, Working Paper in Economics and Development Studies No. 201308.

Irawan, D, Affandi, M I dan Kalsum U. (2013). Analisis Strategi Pengembangan Lembaga Keuangan Mikro Syariah (LKMS) Pedesaan (Studi Kasus BMT Al Hasanah Sekampung), JIIA, Vol. 1(1).

Jamal, A A N dan Sheikh M A. (2013). Challenges Faced by the Model of Islamic Microfinance for the Development of Micro Entrepreneurs and SMEs in Rural Pakistan, International SAMANM Journal of Finance and Accounting, Vol. 1(3).

Juriya, A. M. I. (2013). True Economy Prosperity through Poverty Alleviation

- Islamic Microfinance as Commercial Venture, International Journal of Business, Economics and Law Vol. 2(2).

Kamaluddin, A dan Kasim, N. (2013). The Relationship between Human

Resource Management and Islamic Microfinance Providers' Performance; the Mediating Role of Human Capital, International Journal of Business and Social Science, Vol. 4(16).

Khadijah, S, Saleh, Kamarudin, dan Haryadi. (2013). Sustainability of Islamic Micro Finance Institutions, Universal Journal of Accounting and Finance Vol. 1(2), pp. 70-77. 
Masyita, D dan Ahmed H. (2013). Why Growth Islamic Microfinance Lower Conventional Counterparts in Indonesia, Islamic Economic Studies Vol. 21(1), pp. 35-62.

Putera, B Y. (2013). Study on Risk Management in Financing and Operational of Grameen Bank Financing Concept in MBK Finance, Tazkia Islamic Finance and Business Review Vol. 8(2).

Puteri, H E. (2013). The Revitalization of Women's Entrepreneurship Spirit in MicroEnterprises with Islamic micro- finance Institution (IMI) (Study on The Contribution of BMTs Agam Madani in Agam sub-province, West Sumatra), Tazkia Islamic Finance and Business Review Vol. 8(1).

Rashidah, Abdul Rahman dan Dean Faisal. 2013. Challenges and Solutions in Islamic Microfinance. Humanomics 29(4) pp 293-306.

Riwajanti, N I. (2013). Islamic Microfinance as an alternative for poverty alleviation; a survey, Afro Eurasian Studies, Vol. 2(1\&2), pp. 254-271.

Rokhman, W. (2013). The Effect of Islamic Microfinance on Poverty Alleviation Study in Indonesia, Economic Review- Journal of Economics and Business, Vol. 11(2).

Rozzani, N, Rashidah, Mohamed I S, dan Sharifah. (2013). Applying Technology into Islamic Microfinance.

Rulindo, R dan Pramanik, A H. (2013). Finding a Way to Enhance Impact of Islamic Microfinance; The Role of Spiritual and Religious Enhancement Programmes, Developing Country Studies, Vol. 3(7).

Rusydiana, A S dan Devi, A. (2013). Mengurai Masalah dan Solusi Pengembangan LKMS di Indonesia, Pendekatan Metode BOCR ANP, National Islamic Economic Call Paper and Seminar (NIECS).

Rusydiana, A S dan Devi A. (2013). Challenges in Developing Baitul Maal Wat Tamwiil (BMT) in Indonesia Using Analytic Network Process (ANP), Business and Management Quarterly Review, 4(2), pp. 51-62.

Yusrialis. (2013). Bangkitnya BTM Sebagai Pemberdaya Usaha Mikro Syariah di Indonesia, Menara Vol. 12(2).

\section{Tahun 2012}

Karay, J C. (2012). Analisis Peran Lembaga Keuangan Mikro Terhadap Permberdayaan Usaha Mikro Kecil Di Kabupaten Jayapura (Studi Kasus BPR Nusa Intim Cabang Sentani), Jurnal Ekonomi dan Bisnis, Vol. 2(1), pp. 32-48.

Kholis, N. (2012). The Prospect of Islamic Microfinance Institution in Indonesia, Episteme, Vol. 7(2).

Saad, N Md. (2012). Microfinance and Prospect for Islamic Microfinance Products; the Case of Amanah Ikhtiar Malaysia, Advances in Asian Social Science Vol. 1(1).

Sofi, F J. (2012). Financing Microenterprises; Creating a Potential ValueBased Hybrid Model for Islamic Microfinance, International Journal of Management and Business Research, Vol. 2(2), pp. 108-122. 
Jurnal Ekonomi dan Perbankan Syariah

Vol. 6. No.1, April 2018: 0-26, ISSN (cet): 2355-1755 | ISSN (online): 2579-

6437

| 23

\section{Tahun 2011}

Antonio, M S. (2011). Islamic Microfinance Initiatives to Enhance SME in Indonesia from Historical Overview to Contemporary Situation, Journal of Indonesian Islam, Vol. 5(2).

Bhuiyan, A B, Chamhuri S, Abdul G I, dan Basri, T. (2011). Islamic Microcredit is the Way of Alternative Approach for Eradicating Poverty in Bangladesh: A Review of Islami Bank Microcredit Scheme, Australian Journal of Basic and Applied Sciences, Vol. 5(5), pp. 221230.

Khaled, M. (2011). Building a Successful Business Model for Islamic Microfinance, Global Microcredit Summit Commissioned Workshop Paper.

Smolo, E. (2011). An Overview of Microfinance Sector in Bosnia and Herzegovina: Is There a Room for Islamic Microfinance?, Journal of Islamic Economics, Banking and Finance, Vol. 7(2).

Smolo, E dan Ismail, A G. (2011). A Theory and Contractual Framework of Islamic Microfinance Institution's Operations, Journal of Financial Services Marketing, Vol. 15(4), pp. 287-295.

Worokinasih, S. (2011). Penguatan Kinerja Lembaga Keuangan Mikro Untuk Pemberdayaan Usaha Mikro, Kecil Dan Menengah, Jurnal Akuntansi, Manajemen Bisnis dan Sektor Publik, Vol. 7(2), pp. 252-271.

\section{Tahun 2010}

Ali, M M dan Ascarya. (2010). Analisis Efisiensi Baitul Maal Wat Tamwil Dengan Pendekatan Two Stage Data Envelopment Analysis (Studi Kasus Kantor Cabang BMT MMU Dan BMT UGT Sidogiri), Tazkia Islamic Finance and Business Review, Vol. 5(2).

Gustina dan Ihsan, H. (2010). Integrating Islamic Banking, Zakat and Waqf with Islamic Microfinance in Poverty Alleviation, Jurnal Akuntansi dan Manajemen, Vol. 5(1).

Khan, A. A dan Phillips, I. (2010). The Influence of Faith on Islamic Microfinance Programmes, Islamic Relief Worldwide.

Muttaqien, D. (2010). Urgensi Legalitas Lembaga Keuangan Mikro Syariah, Millah.

Rahman, M. M. (2010). Islamic Micro-Finance Programme and its Impact on Rural Poverty Alleviation, International Journal of Banking and Finance, Vol. 7(1).

Saad, N Md dan Duasa, J. (2010). Determinants of Economic Performance of Micro-Credit Clients and Prospects for Islamic Microfinance in Malaysia, ISRA International Journal of Islamic Finance, Vol. 2(1).

\section{Tahun 2009}

Ahmad, Abu Umar Faruq. (2009). Islamic Microfinance: The Evidence from Australia, Humanomics Vol. 25(3) pp 217-235. 
Akhter, W, Akhtar, N dan Jaffri, S K A. (2009). Islamic Micro Finance and Poverty Alleviation: A Case of Pakistan, Proceeding $2^{\text {nd }}$ CBRC, Lahore, Pakistan.

Bakhtiari, S. (2009). Islamic Microfinance, Providing Credit to the Poor: A Case Study of Iran, International Economics Studies, Vol. 34(1), pp. 99-107.

Dogarawa, A B. (2009). Framework for an Effective Islamic Micro Finance in Northern Nigeria, Paper Presented at the First Islamic Summit, Kano Organised by the Muslim Centre for Research and Planning, Centre for Islamic Legal Studies, Ahmadu Bello University, Zaria Held at Tahir Guest Palace, Kano, Nigeria.

Saad, N Md dan Anuar, A. (2009). Cash Waqf and Islamic Microfinance Untapped Economic Opportunities, Islam Civilisational Renewal (ICR), Vol. 1(2).

\section{Tahun 2008}

Frasca, A. (2008). A FURTHER NICHE MARKET; Islamic Microfinance in the Middle East and North Africa.

Mohammed, A D dan Hasan, Z. (2008). Microfinance in Nigeria and the Prospects of Introducing Its Islamic Version there in the Light of Selected Muslim Countries' Experiences.

Wahyuni, E T. (2008). The Accountability of Islamic Microfinance Institution, an Evidence from Indonesia, Journal the WINNERS, Vol. 9(1), pp. 2234.

\section{Tahun 2007}

Ascarya dan Sanrego, Y D. (2007). Redefine Micro, Small, and Medium Enterprises Classification and the Potency of Baitul Maal wa Tamwiel as Intermediary Institutions in Indonesia, Jurnal Ekonomi dan Bisnis Islam Edisi II.

Norhaziah Binti N dan Bashir, M S. (2007). Measuring Performance of Amanah Ikhtiar Malaysia (AIM) in Eradication Poverty, Proceedings of the $2^{\text {nd }}$ Islamic Conference 2007 (iECONS2007) organized by Faculty of Economics and Muamalat, Islamic Science University of Malaysia.

Rahman, A. R. A. (2007). Islamic Microfinance: A Missing Component in Islamic Banking, Kyoto Bulletin of Islamic Area Studies, vol. 1(2), pp. $38-53$.

Seibel, H D. (2007). Islamic Microfinance in Indonesia the Challenge of Institutional Diversity Regulation and Supervision, A Symposium 2007.

Wilson, R. (2007). Making Development Assistance Sustainable Through Islamic Microfinance, IIUM Journal of Economics and Management Vol. 15(2), pp. 197-217. 